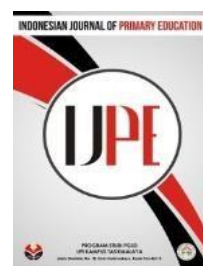

\title{
terhadap Kemampuan Membaca Pemahaman dan Kecerdasan Interpersonal Siswa SD
}

\author{
Dika Zuchdan Sumira ${ }^{1}$, Deasyanti ${ }^{2}$, Tuti Herawati ${ }^{3}$ \\ Universitas Negeri Jakarta \\ *Corresponding author: dikazuchdan21@gmail.com, deasy.edupsy@yahoo.com, tutiherawati2@yahoo.co.id
}

Diterima 31 Agustus 2017; Direview 28 September 2017; Diterima 24 Oktober 2017

Diterbitkan online 21 Desember 2017

\begin{abstract}
Abstrak
Tujuan dari penelitian ini adalah untuk mengetahui pengaruh penerapan metode pembelajaran Scramble terhadap kemampuan membaca pemahaman dan kecerdasan interpersonal siswa pada pembelajaran Bahasa Indonesia pada siswa kelas IV Sekolah Dasar. Penelitian dilakukan di SDIT Segar Amanah Klender Jakarta Timur dengan sampel siswa kelas IVA 28 orang sebagai kelas eksperimen dan kelas IV B dengan sampel siswa 28 orang sebagai kelas kontrol yang dilaksanakan pada semester 1 tahun ajaran 2017/2018. Sampel yang digunakan dalam penelitian ini menggunakan random sampling. Teknik penelitian menggunakan metode eksperimen dengan desain quasi eksperimen. Teknik pengumpulan data dilakukan dengan menggunakan lembar tes dan lembar observasi untuk mengetahui kemampuan membaca pemahaman kecerdasan interpersonal pada pembelajaran Bahasa Indonesia, dengan terlebih dahulu dilakukan pengujian validitas dan realibilitas serta Justivication expert dan uji norrmalitas dan homogenitas baik kelas eksperimen yang menggunakan metode pembelajaran Scramble ataupun kelas kontrol yang menggunakan model pembelajaran ekspositori. Hasil pengujian menunjukan bahwa kedua kelas berdistribusi normal serta menunjukan homogenitas kedua kelas tersebut homeogen. Hasil penelitian menunjukan kenaikan rata-rata kemampuan membaca pemahaman kelas eksperimen dari 59,5 menjadi 86,5 sedangkan kelas Kontrol dari 60,5 menjadi 67,5, kecerdasan interpersonal rata-rata kelas eksperimen dari 55,5 menjadi 88,5 dan 57,5 menjadi 66 untuk kelas kontrol. serta keefektifan proses pembelajaran apabila melihat rata-rata Normal Gain kelas eksperimen lebih tinggi dibandingkan dengan kelas kontrol. Normal Gain kemampuan membaca pemahaman untuk kelas eksperimen mendapatkan nilai 0,68 dengan kategori cukup efektif, sementara kelas kontrol mendapatkan kategori tidak efektif dengan nilai 0,29. Normal Gain Kecerdasan interpersonal kelas eksperimen menunjukan nilai 0,76 dan kelas kontrol dengan Normal Gain sebesar 0,37. Berdasarkan hasil penelitian tersebut, dapat disimpulkan kemampuan membaca pemahaman dan kecerdasan interpersonal siswa pada pembelajaran Bahasa Indonesia kelas eksperimen lebih baik daripada kemampuan membaca pemahaman dan kecerdasan interpersonal siswa pada pembelajaran Bahasa Indonesia kelas kontrol.
\end{abstract}

Kata Kunci: Metode, Scramble, Membaca, Pemahaman, Kecerdasan, Interpersonal.

\section{PENDAHULUAN}

Proses pendidikan yang dilaksanakan di sekolah mengharapkan siswa dapat mengembangkan potensi terbaiknya sesuai dengan tujuan pembelajaran. Guru sebagai pengajar bukan hanya sekedar menyampaikan informasi terkait dengan materi pembelajaran, akan tetapi harus mampu menciptakan suasana kelas yang menyenangkan supaya siswa terlibat aktif dalam proses pembelajaran serta siswa dapat mengembangkan seluruh kemampuan yang ada pada dalam dirinya. Hal ini sejalan dengan UU No. 20 tahun 2003 tentang sistem pendidikan nasional, bahwa pendidikan adalah usaha sadar dan terencana untuk mewujudkan suasana belajar dan proses pembelajaran agar peserta didik secara aktif mengembangkan potensi dirinya untuk memiliki kekuatan spiritual keagamaan, pengendalian diri, kepribadian, kecerdasan, akhlak mulia, serta keterampilan yang diperlukan dirinya, masyarakat, bangsa dan negara. 
Di setiap jenjang pendidikan khususnya di Sekolah Dasar, peserta didik diharuskan menempuh sejumlah mata pelajaran tertentu, diantaranya adalah mata pelajaran Bahasa Indonesia.

Menurut Rahmat (2017,hlm.29) menyatakan bahwa pembelajaran Bahasa Indonesia merupakan mata pelajaran yang menitikberatkan pada kompetensi berbicara, menulis dan membaca. Mata pelajaran Bahasa Indonesia Sekolah Dasar menuntut para siswa untuk dapat memahami konteks bacaan, sumber bacaan, kemampuan untuk berliterasi, kemampuan untuk menulis dan kemampuan dalam berbicara sesuai dengan kaidah dan ejaan yang tepat.

Ruang lingkup mata pelajaran Bahasa Indonesia mencakup komponen kemampuan berbahasa dan kemampuan bersastra yang meliputi aspek mendengarkan, menulis, membaca dan berbicara. Salah satu keterampilan yang sangat penting dikuasai oleh siswa adalah keterampilan membaca.

Menurut Yunus (2012,hlm.59) Jenis keterampilan membaca salah satunya adalah keterampilan membaca pemahaman. Menurut Tarigan (Putri Amma,2013,hlm. 856) membaca pemahaman (reading for undersanding) adalah jenis membaca untuk memahami standarstandar atau norma kesastraan, resensi kritis, drama tulis, dan pola-pola fiksi dalam usaha memperoleh pemahaman terhadap teks, pembaca menggunakan strategi tertentu. Keterampilan membaca pemahaman bukan hanya sekedar asal membaca saja akan tetapi harus didasari dengan pemahaman akan makna atau isi dari bacaan baik yang tersirat maupun tersurat.

Organization For Economic Cooperation and Develpoment (OECD) melalui Program for International Student Assessment (PISA) dalam literasi membaca pada tahun 2015 menempatkan Indonesia pada urutan bawah yaitu menempati posisi ke 63 dari 72 negara yang berpartisipasi. Baik tahun 2012 ataupun 2015, hasil nilai literasi membaca yang di peroleh Indonesia masih dibawah rata-rata skor 500 dari nilai yang ditetapkan PISA. Yaitu hanya mencapai Low Internasional Bencmark. (OECD,2015,hlm.5). Selain literasi membaca Indonesia yang masih tergolong rendah, kemampuan membaca anak Indonesia khususnya siswa Sekolah Dasar kelas IV masih juga tergolong rendah. Hal ini terbukti berdasarkan studi yang dilakukan Progress in International Reading Literacy Study (PIRLS) pada tahun 2011, menunjukan hasil bahwa kemampuan membaca siswa SD/MI kelas IV di Indonesia tergolong rendah, hanya 5\% siswa Indonesia yang diteliti menunjukan kemampuan membacanya sampai tingkat high dan advance, sementara lebih dari 30\% tingkatannya very low, hampir $40 \%$ hanya tingkat low dan bahkan hanya $25 \%$ saja siswa yang mencapai tingkat intermediate. (Wawan Krimanto,2015,hlm. 235) Artinya berdasarkan studi yang dilakukan oleh PISA dan PIRLS bahwa literasi membaca dan kemampuan membaca pemahaman masih jauh dari apa yang diharapkan. Oleh karena itu pengembangan kompetensi dalam aspek membaca perlu diperhatikan salah satunya dengan 
menggunakan beragam metode pembelajaran yang disesuaikan dengan karakteristik siswa.

Pelaksanaan pembelajaran Bahasa Indonesia perlu dirancang dengan berorientasi pada kemampuan menulis, membaca dan berbicara. Kemampuan tersebut menuntut siswa untuk bersikap ilmiah dalam memahami dan menyelesaikan permasalahan. Bahasa Indonesia merupakan salah satu mata pelajaran yang dianggap kurang menarik oleh kalangan siswa Sekolah Dasar. Sebagian diantara siswa Sekolah Dasar tidak menyukai mata pelajaran Bahasa Indonesia dikarenakan faktor strategi pembelajaran yang dilakukan guru kurang inovatif. Strategi yang inovatif dan kontrstuktif akan mampu memberikan wawasan pengetahuan siswa serta meningkatkan aktivitas dan kreativitas siswa dalam proses pembelajaran. Selain dari itu, salah satu bentuk harapan sebuah pembelajaran adalah mengarah pada keterampilan sosial, baik kemampuan untuk melakukan interaksi, sosialisasi serta memiliki kepekaan terhadap sesama. Kecerdasan Interpersonal merupakan suatu kemampuan untuk dapat menjalin hubungan dengan keterampilan maupun kepekaan terhadap orang disekelilingnya, yang timbul karena adanya kebutuhan, empati, rasa kasih sayang, ekspresi diri dan pengaruh dari adanya stimulus. (Yaumi,2012,hlm.143).

Kecerdasan interpersonal dituntut guna sebagai upaya peningkatan kepedulian siswa terhadap sosial, baik memiliki empati, kasih sayang maupun kepedulian terhadap sesama. Kecerdasan interpersonal juga disebut sebagai kecerdasan sosial dimana seseorang mampu menciptakan relasi, mempertahankan hubungan serta membangun hubungan baru. (Safaria,2005,hlm.23).

Monawati, (2015,hlm.21-32) menyatakan bahwa dengan kecerdasan interpersonal siswa akan memiliki kepekaan terhadap lingkungan sosialnya baik ketika bermain, belajar atau di lingkungan masyarakat. Selain dari itu, kecerdasan interpersonal dapat mempengaruhi terhadap hasil belajar siswa serta diantara keduanya terdapat hubungan yang satu sama lain sangat berhubungan.

Untuk menumbuhkan kemampuan membaca pemahaman siswa disertai dengan kecerdasan interpersonal siswa yang mumpuni maka perlu adanya strategi yang relevan yang dapat dijadikan suatu solusi untuk pemecahan masalahnya. Penerapan metode pembelajaran yang relevan dengan kebutuhan dan karakteristik siswa sekolah dasar yang operasional konkrit dapat mampu memebrikan proses pembelajaran yang efektif, maksimal dan optimal sehingga tujuan pembelajaran dan penelitian dapat tercapai dengan maksimal.

Scramble berasal dari bahasa Inggris yang diterjemahkan dalam bahasa Indonesia yang memiliki arti perebutan, pertarungan, dan perjuangan. Model pembelajaran scramble merupakan model pembelajaran yang mengajak siswa untuk menemukan jawaban dan menyelesaikan permasalahan yang ada dengan cara membagikan lembar kartu soal dan jawaban yang disertai dengan alternatif jawaban yang tersedia. (Shoimin, 
2016,hlm.160)

Pembelajaran kooperatif tipe scramble merupakan salah satu model pembelajaran yang melibatkan beberapa siswa dalam kelompok untuk bekerja sama menjawab pertanyaan yang diajukan oleh guru dengan cara menyusun huruf menjadi kata, kata menjadi kalimat, atau kalimat yang teracak menjadi sebuah paragraf yang utuh dan bermakna. ( Sudarmi, 2017, hlm. 73)

Berdasarkan beberapa pengertian tersebut dapat diartikan bahwa model pembelajaran scramble merupakan model pembelajaran kelompok yang menekankan konsep belajar sambil bermain, karena model ini menggunakan kartu-kartu seperti kartu huruf, kartu kalimat, dan kartu paragraf sehingga siswa dalam kelompok berusaha memecahkan permasalahan dengan menggunakan kartu tersebut. Berdasarkan hal tersebut penerapan metode ini akan lebih memberikan kesempatan kepada siswa untuk terlibat aktif, sosialisasi, interaktif dan melakukan komunikasi antar siswa. berdasarkan hal tersebut maka disamping memberikan peningkatan terhadap kemempuan membaca pemahaman siswa, juga dapat memberikan peningkatan dan pengaruh bagi kecerdasan interpersonal dalam diri siswa.

Adapun langkah-langkah metode scramble yang perlu dilakukan adalah sebagai berikut:

a. Guru menyiapkan sebuah wacana, kemudian keluarkan kalimat-kalimat yang terdapat dalam wacana tersebut ke dalam kartu-kartu kalimat

b. Guru membuat kartu soal beserta kartu jawaban yang diacak nomornya sesuai materi bahan ajar teks yang telah dibagikan sebelumnya dan membagikan kartu soal tersebut

c. Siswa dalam kelompok masing-masing mengerjakan soal dan mencari kartu soal untuk jawaban yang cocok, sebelumnya jawaban telah diacak sedemikian rupa

d. Siswa diharuskan dapat menyusun kata jawaban yang telah tersedia dalam waktu yang ditentukan

e. Setelah selesai mengerjakan soal, hasil pekerjaan siswa dikumpulkan dan dilakukan pemeriksaan. (Bahri, 2006,hlm.90-91)

\section{METODE}

Dalam Penelitian ini peneliti menggunakan pendekatan kuantitatif dengan metode penelitian eksperimen. Metode penelitian eksperimen adalah metode penelitian yang digunakan untuk mencari pengaruh perlakuan tertentu terhadap yang lain dalam kondisi yang terkendalikan. Sugiyono (2012, hlm.72). Desain penelitian yang digunakan oleh peneliti adal quasi eksperimen hal ini dimaksudkan karena tujuan dari penelitian ini adalah untuk mengukur sejauh mana pengaruh metode pembelajaran Scramble terhadap kemampuan membaca pemahaman dan kecerdasan interpersonal siswa pembelajaran Bahasa Indonesia.

Adapun populasi dalam penelitian ini adalah siswa kelas IV A dan siswa kelas IV B SDIT Segar Amanah Kecamatan Duren Sawit Kota Jakarta Timur dengan teknik sampel yang digunakan adalah teknik sampel jenuh. Sampel berjumlah 56 orang siswa kelas IV SDIT Segar (C) 2017 - Indonesian Journal of Primary Education - Vol. 1, No. 2 (2017) 70-76 - http://ejournal.upi.edu/index.php/IJPE/index 
Amanah Kecamatan Duren Sawit Kota Jakarta Timur, dengan rincian 28 orang siswa kelas IV A sebagai kelompok eksperimen dan 28 orang siswa kelas IV B sebagai kelompok kontrol. Adapun desain yang digunakan adalah Nonequivalent Control Group Design. Instrumen penelitian terdiri dari tes, lembar angket, dan lembar observasi.

\section{HASIL DAN PEMBAHASAN}

Hasil penelitian ini berhubungan dengan pengaruh metode pembelajaran Scramble terhadap kemampuan membaca pemahaman dan kecerdasan interpersonal siswa pembelajaran Bahasa Indonesia di kelas IV SDIT Segar Amanah Kecamatan Duren Sawit Kota Jakarta Timur. Diadakannya penelitian ini, bertujuan untuk melihat peningkatan kemampuan membaca pemahaman dan kecerdasan interpersonal siswa pada pembelajaran Bahasa Indonesia. Dalam penelitian ini, terdapat dua kelas yang dijadikan sampel penelitian, dengan jumlah keseluruhan 56 orang siswa kelas IV SDIT Segar Amanah Kecamatan Duren Sawit Kota Jakarta Timur, dengan rincian 28 orang siswa kelas IV A sebagai kelompok eksperimen dan 28 orang siswa kelas IV B sebagai kelompok kontrol. Berikut hasil analisis data yang telah dilakukan.

a. Analisis data kelas kontrol

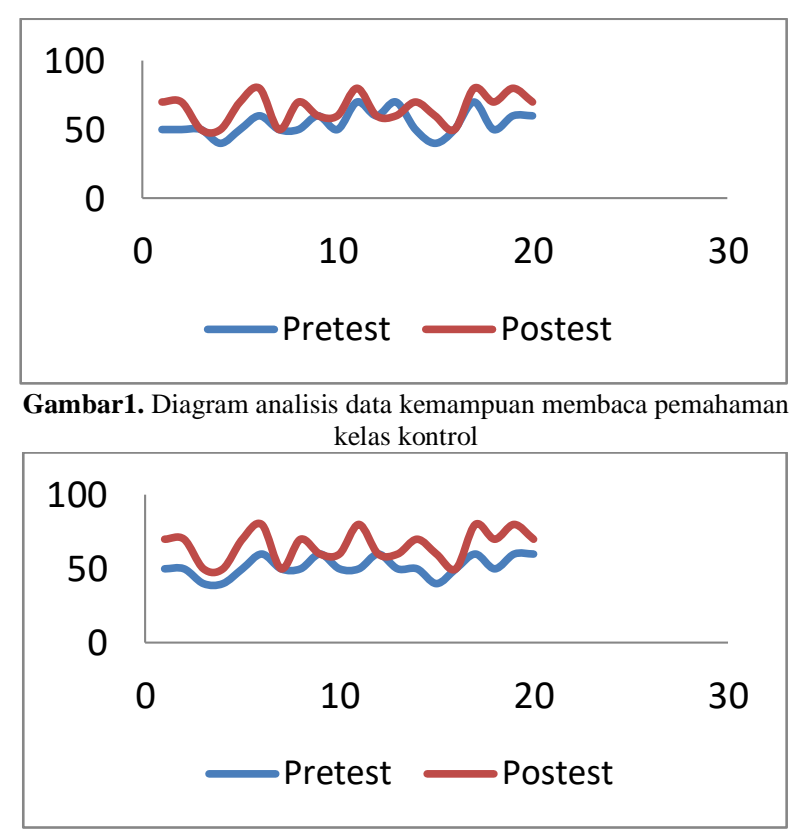

Gambar 2. Diagram analisis data Kecerdasan Interpersonal kelas kontrol

Dengan melihat gambar 1 terkait kemampuan membaca pemahaman dan gambar 2 kecerdasan interpersonal siswa dalam pembelajaran Bahasa Indonesia diatas, dapat diambil kesimpulan bahwa kemampuan membaca pemahaman awal siswa kelas kontrol tanpa menggunakan metode Scramble dengan nilai pretest 60,5 dan posttest 67,5 .

Hal ini menunjukan tidak adanya kenaikan yang signifikan baik pada saat awal penelitian sampai akhir penelitian apabila dibandingkan dengan kelas eksperimen. Selanjutnya, kecerdasan interpersonal siswa kelas kontrol didapatkan data pretest dengan nilai rata-rata 59,5 dan posttest sebesar rata-rata 86,5.

b. Analisis Data Kelas Eksperimen

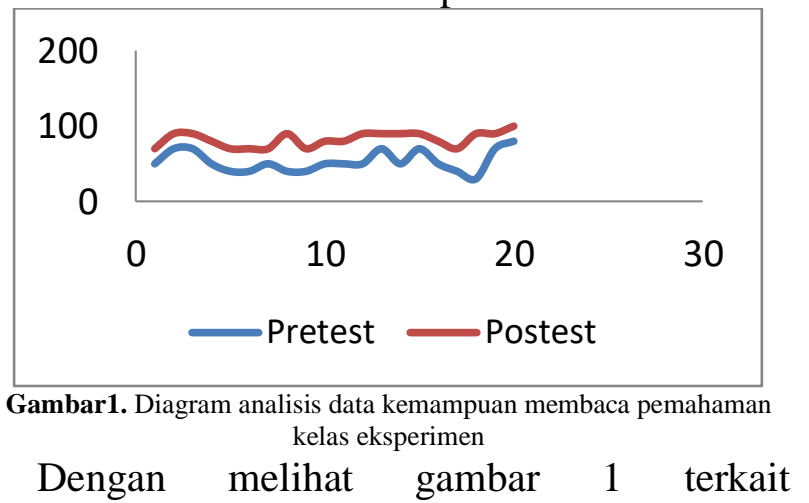


kemampuan membaca pemahaman sebelum perlakuan dan gambar 2 kecerdasan interpersonal siswa dalam pembelajaran Bahasa Indonesia diatas, dapat diambil kesimpulan bahwa kemampuan membaca pemahaman siswa kelas Eksperimen dengan menggunakan metode Scramble dengan nilai pretest 59,5 dan posttest 86,5 . Hal ini menunjukan adanya kenaikan yang signifikan baik pada saat awal penelitian sampai akhir penelitian apabila dibandingkan dengan kelas kontrol. Selanjutnya, kecerdasan interpersonal siswa kelas kontrol didapatkan data pretest dengan nilai rata-rata 55,5 dan posttest sebesar ratarata 88,5 .

Analisis Perbandingan Kemampuan Membaca Pemahaman dan Kecerdasan Interpersonal Siswa Kelas Kontrol dan Kelas Eksperimen

Table 1. Perbandingan kelas kontrol dan eksperimen

\begin{tabular}{|c|c|c|c|c|c|}
\hline \multirow[b]{2}{*}{ Kelas } & \multirow[b]{2}{*}{$\begin{array}{l}\text { Fokus } \\
\text { Penelitian }\end{array}$} & \multicolumn{3}{|c|}{ Nilai Rata-rata } & \multirow{2}{*}{$\begin{array}{l}\text { Kualitas } \\
\text { Hasil } \\
\text { Belajar }\end{array}$} \\
\hline & & Pretest & $\begin{array}{l}\text { Postt } \\
\text { est }\end{array}$ & $\begin{array}{l}\text { Normal } \\
\text { Gain }\end{array}$ & \\
\hline \multirow[t]{2}{*}{ Kontrol } & $\begin{array}{l}\text { Kemampuan } \\
\text { membaca } \\
\text { pemahaman }\end{array}$ & 60,5 & 67,5 & 0,29 & $\begin{array}{l}\text { Tidak } \\
\text { Efektif }\end{array}$ \\
\hline & $\begin{array}{l}\text { Kecerdasan } \\
\text { Interpersonal }\end{array}$ & 57,5 & 66 & 0,37 & $\begin{array}{l}\text { Tidak } \\
\text { Efektif }\end{array}$ \\
\hline \multirow[t]{2}{*}{ Eksperimen } & $\begin{array}{l}\text { Kemampuan } \\
\text { membaca } \\
\text { pemahaman }\end{array}$ & 59,5 & 86,5 & 0,68 & $\begin{array}{l}\text { Cukup } \\
\text { Efektif }\end{array}$ \\
\hline & $\begin{array}{l}\text { Kecerdasan } \\
\text { Interpersonal }\end{array}$ & 55,5 & 88,5 & 0,76 & $\begin{array}{l}\text { Sangat } \\
\text { Efektif }\end{array}$ \\
\hline
\end{tabular}

Dari tabel 1 di atas diketahui bahwa nilai rata-rata kemampuan membaca pemahaman pretest di kelas kontrol yaitu 60,5 sedangkan untuk nilai rata-rata untuk kelas eksperimen yaitu 59,5. Dilihat dari nilai rata-rata pretest pada kelas kontrol tidak efektif dan kelas eksperimen mempunyai kategori cukup efektif. Hasil posttest kemampuan membaca pemahaman di kelas kontrol yaitu 67,5, sedangkan untuk kelas eksperimen yaitu 86,5. Hasil posttest pada kelas kontrol mendapat kategori tinggi sedangkan dikelas eksperimen mendapat kategori sangat tinggi.

Selanjutnya, nilai rata-rata kecerdasan interpersonal pretest di kelas kontrol yaitu 57,5 sedangkan untuk nilai rata-rata untuk kelas eksperimen yaitu 55,5. Dilihat dari nilai ratarata pretest pada kelas kontrol tidak efektif dan kelas eksperimen mempunyai kategori cukup efektif. Hasil posttest kecerdasan interpersonal di kelas kontrol yaitu 66, sedangkan untuk kelas eksperimen yaitu 88,5. Hasil posttest pada kelas kontrol mendapat kategori cukup efektif sedangkan dikelas eksperimen mendapat kategori sangat efektif.

\section{KESIMPULAN}

Berdasarkan data-data yang terhimpun melalui data kualitatif dan kuantitatif maka dapat disimpulkan bahwa metode Scramble memberikan pengaruh terhadap kemampuan membaca pemahaman dan kecerdasan interpersonal pada pembelajaran Bahasa Indonesia. Hal ini terbukti dengan melihat nilai rata-rata dari kelas kontrol dan eksperimen SDIT Segar Amanah Kecamatan Duren Sawit Kota Jakarta Timur, jika melihat efektivitas proses pembelajaran kelas eksperimen lebih baik dibandingakn kelas kontrol dengan kategori cukup efektif dan untuk kelas kontrol tidak efektif

Implikasi diadakannya penelitian dengan menggunakan metode Scramble terhadap pasrtisipan yaitu, adanya peningkatan kemampuan membaca pemahaman dan kecerdasan interpersonal pada pembelajaran Bahasa Indonesia baik melalui pemahaman, 
sikap, dan keterampilan siswa dalam proses pembelajaran. Meningkatnya pemahaman siswa dapat dilihat dari peningkatan hasi pretest dan posttest yang dilakukan siswa.

\section{REFERENSI}

Shoimin, A. (2014). 68 Model Pembelajaran Inovatif dalam Kurikulum 2013.Bandung: Ar Ruzz Media.

Bahri, S. dkk. (2006). Strategi Belajar Mengajar. Jakarta: PT Rineka Cipta.

Monawati. (2015). Hubungan antara kecerdasan interpersonal dengan Prestasi Belajar.Jurnal Pesona Dasar PGSD Universitas Syiah Kuala. Vol. 3 No.3, April 2015, hal 21 - 32, ISSN: 2337-9227

Organization Of Economic Cooperation And Development. (2015). Programme for International Student Assessment 2015 Result in Focus. (OECD:2015).

Amma, P. dkk. (2013). Meningkatkan Kemampuan Membaca Pemahaman Pada Siswa Tunarungu Dengan Menggunakan Teknik Skimming. Jurnal Ilmiah Pendidikan Khusus; Volume 2, Nomor 3, September 2013 Pendidikan Luar Biasa, FIP UNP.

Rahmat. (2017). Games Book sebagai Media Peningkatan Minat Baca pada Pembelajaran Bahasa Indonesia SD Kelas Tinggi. Jurnal IJPE UPI, Vol 1 No 1 (2017) 27-33.
Safaria. (2005). Personal Intelligences Metode Pengembangan Kecerdasan Interpersonal Anak. Yogyakarta:Amara Books.

Sugiyono. (2012). Metode Penelitian Kuantitatif Kualitatif dan $R \& D$. Bandunga: Alfabeta.

Sudarmi \& Burhanuddin. (2017). Keefektifan Model Pembelajaran Kooperatif Tipe Scramble Dalam Keterampilan Menulis Kalimat Bahasa Jerman Siswa Kelas XI SMA Negeri 11 Makassar.Jurnal Pendidikan Bahasa Asing dan Sastra, Volume 1, Nomor 1, Maret 2017, Universitas Negeri Makassar.

Undang-Undang Sistem Pendidikan Nasional No 20 tahun 2003. Jakarta: DEPDIKNAS.

Wawan Krimanto, Abdul Khalik, Sayidiman. "Meningkatkan Kemampuan Membaca Pemahaman Melalui Metode Survey, Question, Read, Recite, Review (SQ3R)," Jurnal Publikasi Pendidikan; Volume 5, Nomor 3, September 2015 PGSD UNM.

Yaumi. (2012). Pembelajaran Berbasis Multiple Intellegences. Jakarta: Dian Rakyat.

Yunus Abidin. (2012) . Pembelajaran Membaca Berbasis Pendidikan Karakter. Bandung: PT Refika Aditama.

Zulela. (2012). Pembelajaran Bahasa Indonesia. Bandung: PT Remaja Rosdakarya 